\title{
Eho ratne traume: na dugim prugama između Maribora i Kraljeva
}

Sažetak

U radu se analiziraju korelacije između Maribora i Kraljeva, uspostavljene na međuljudskim odnosima u prošlosti. Rad prati genezu tih odnosa, od migracija Slovenaca koji su svoje stanište u međuratnom periodu, ili izbegličko utočište u Drugom svetskom ratu pronalazili na području Kraljeva, do eha traumatične prošlosti kroz posleratne manifestacije: „Povelje“ o bratimljenju Maribora i Kraljeva, vozove „Bratstva-jedinstva“, memorijale u Spomen-parku u Kraljevu. Akcentuju se uzroci kolektivnih prinudnih migracija i fokusira socijalno i društveno najugroženiji demografski sloj tokom okupacije. To su bile žrtve ratnih aspiracija i odluka sila moći na koje žrtve nisu mogle uticati, a usled kojih su izgubile bližnje, dom, imovinu, status. Slovenačke izbeglice su sa žiteljima Kraljeva i okoline, među kojima i sa svojim sunarodnicima, predratnim stručnim radnicima i službenicima $u$ kraljevačkim fabrikama i pri železničkom čvoru, podelile okupacione nedaće - život u oskudici i strah od ubistava na kućnom pragu ili u masovnim odmazdama, od kojih je najpogubnija bila u kraljevačkom Lageru, u oktobru 1941. godine. Akcentovani lični, porodični fragmenti u kolektivnoj slici zajedničke traumatične prošlosti posmatraju se i kroz refleksije u kasnijim odnosima ljudi sa dva udaljena područja.

Ključne reči: migracije, vozovi, Drugi svetski rat, Slovenija, izbeglice, Kraljevo, streljanje, lager

\section{Uvod}

Suživot slovenačkog i srpskog stanovništva u teškim uslovima okupacije, kada su - usled ekspanzionih ciljeva Trećeg Rajha da teritoriju Slovenije pripoji i njeno stanovništvo germanizuje ili protera - izgnanici našli utočište u Srbiji, predstavlja polazište poslera- 
tnih manifestacija prijateljstva između dva naroda. Bratimljenje na nivou gradova, između Kraljeva i Maribora, uspostavljeno je na ličnim i porodičnim vezama između nekadašnjih izgnanika i njihovih domaćina, kao i na sačuvanom sećanju na njihove bližnje, streljane u masovnoj odmazdi na kraljevačkom stratištu, u oktobru 1941. godine. ${ }^{1}$ Eho zajedničke traumatične prošlosti odzvanjao je u ratnim i posleratnim generacijama, kada su, od 1961. godine, u susretima novinara mariborskog lista „Večer“ i svetozarevačkog „Novog puta“ uspostavljane trase manifestacije „Voz - vlak bratstva i jedinstva“. ${ }^{2}$ Posle dve decenije, nekadašnjom trasom izbegličkih transporta krenulo je oko 640 putnika iz Ljubljane, uz bivše izgnanike koji su se $\mathrm{u}$ vozu pridruživali na gotovo svim stanicama do Zidanog Mosta, $\mathrm{u}$ ovoj posebnoj misiji prijateljstva (Radović, Marković 2016, 19). Sa beogradske železničke stanice, u svečarskoj atmosferi, prilikom dočeka 15. septembra 1961. godine, kompozicije su krenule dalje prugama Šumadije do stanica u Svetozarevu (Jagodini), Ćupriji, Stalaću, Vrnjačkoj Banji, Kraljevu i Čačku. Putovanje „Voza“ kroz Srbiju, dočekivanog cvećem i dobrodošlicama, onovremena „Borba“ opisala je kao dirljiv susret starih prijatelja i poznanika, čije se prijateljstvo stvaralo u najtežem vremenu i nad zajedničkim humkama: „U Kraljevu su gosti za vreme trodnevnog boravka položili vence na groblje žrtava fašističkog terora. Posle posete porodicama obišli su fabriku Magnohrom, a zatim Matarušku Banju i manastir Žiču." (Borba, 19. septembar 1961). Kada je put Maribora, u uzvratnu posetu, krenulo 1962. godine oko 350 učesnika, mnogima su u sećanju ostali pažnja, poštovanje i ljubav koji su im upućeni i sažeti u rečima književnika Frana Roša: „Hvala vam braćo Srbi na svemu što ste učinili za nas. Naša krv se u najtežim trenucima mešala sa vašom krvlju. Zato se mi danas tako toplo osećamo. Nalazimo se u večnom zagrljaju i ne-

\footnotetext{
${ }^{1}$ Detaljni poimenični pregledi slovenačkih izbeglica i slovenačkih žrtava masovne odmazde, na osnovu istraženih izvora, publikovani su u radovima: Krejaković S., Strle U. (2011). Rekvijem za harmoniku: Slovenci u kontekstu masovne odmazde u Kraljevu, Dve domovini / Two Homelands 33: 73-88; Крејаковић С. (2009). Словенци избеглице у Краљеву у време окупације (19411944). Наша прошлост 10: 139-155.

${ }^{2}$ Ideju o uspostavljanju voza i susretima nekadašnjih izgnanika i njihovih domaćina osmislili su novinari Branko Senica, Jože Gal, Franjo Roš, Stanko Čretnik, Dragoljub Mladenović. Navedeno prema: Radović R., Marković J. (2016). Voz bratstvojedinstvo (1961-1989), katalog izložbe. Kraljevo : Istorijski arhiv Kraljevo.
} 
ma te sile koja će razrušiti naše bratstvo i jedinstvo" (Marinković i dr. 1973, 237).

Od godine 1966. uspostavljeni su dolasci vozova iz Slovenije za 14. oktobar, kako bi delegacije iz slovenačkih gradova, bivši prognanici i rodbina streljanih talaca 1941. godine prisustvovali programima komemorativne svečanosti u kraljevačkom Spomen-parku. Nedugo potom, 1970. godine, na Komemorativnoj sednici SO Kraljeva, održanoj 14. oktobra, u prisustvu potpredsednika Savezne skupštine Miloša Minića, kao i delegacija iz 52 opštine u Jugoslaviji, te republičkih delegacija iz Slovenije i Srbije, potpisana je Povelja o bratimljenju opština Kraljevo i Maribor. ${ }^{3}$ Iz Kraljeva je ka Mariboru 1976. godine krenulo 1.100 predstavnika 31 opštine u Srbiji, među kojima su njih 28 bile potpisnici Povelje o bratimljenju sa opštinama u Sloveniji. Vozovi su naizmenično, najpre godišnje, a potom svake druge-treće godine, ukupno njih 18 do sredine osamdesetih, bili manifestacije prijateljstva, bratstva dva naroda i dva grada. Istovremeno, zajedničke omladinske brigade bratimljenih gradova učestvovale su na velikim radnim akcijama - manifestacijama društvenog i idejnopolitičkog organizovanja mladih u izgradnji Jugoslavije (Janićijević 1999). Poslednji „Vlak“ stigao je u kraljevačku stanicu 13. oktobra 1989. godine. Usledili su politički i, potom, vojni sukobi političkih elita, kada su i vozovi, uprkos zakletvama „da nikada neće stati“, kao i pojmovi bratstva i jedinstva i Jugoslavije, otputovali u istoriju. Oružani napadi na vojsku JNA na tlu Slovenije, u kojima je poginuo vojnik iz Kraljeva, posebno su emotivno doživljeni kao izdaja zajedničkih vrednosti, utemeljenih nad zajedničkim humkama i kao „prijateljstvo u plamenu“ (Stanojević 1991, 1). Skupština Opštine Kraljevo donela je Odluku da se gradu Mariboru vrati Povelja o bratimljenju i da se sa Opštinom Maribor prekinu sve kulturne i druge veze koje proističu iz Povelje. ${ }^{4}$

\footnotetext{
${ }^{3}$ Istorijski arhiv Kraljevo (dalje IAK), fond: SO Kraljevo, ib. 239, Zapisnik sa sednice, 14. 10. 1970. Potpisnici Povelje bili su predsednik Skupštine opštine Maribor Mirko Žlender i predsednik Skupštine opštine Kraljevo dr Milenko Mojsilović.

${ }^{4}$ U obrazloženju Odluke navedeno je: „Obzirom da niste pokazali ni malo milosti prema toj deci vojnicima JNA, ni malo humanosti, ne poštujući ni osnovna načela Ženevske konvencije, definitivno smo shvatili da mrzite sve što je srpsko pa naša Povelja gubi svaki smisao." Narodni Muzej Kraljevo (dalje NMK), Odluka Skupšine opštine Kraljevo sa sednice Veća mesnih zajednica, kopija dokumenta, br. 06-91, 2. jula 1991.
} 
Kada je oružje iz poslednjih oružanih sukoba utihnulo, zahvaljujući retkim, uporednim terenskim istraživanjima na oba područja, stiče se realnija slika o međusobnim odnosima i kontaktima, koji su počeli kao individualna i porodična dopisivanja nekadašnjih izgnanika i njihovih domaćina, prerasli u bratimljenje dva grada, manifestovano kroz naizmenične grupne posete vozom, podržavano zvaničnim ideološkim stereotipima o „večitom bratstvu i jedinstvu“ - do njihovog kraha (Pavlović 2016). Obnavljanje pokidanih i uspostavljenje novih veza između dva grada realizuje se posle političkih promena u Srbiji, na inicijativu pojedinaca i udruženja Prijateljstvo za nova vremena $\mathrm{u}$ Kraljevu. Činilo se da kao eho odzvanja zajednička prošlost i inicira kulturnu i privrednu saradnju, koju uspostavljaju delegacije dva grada. Simboličnu potvrdu da su u međusobnim odnosima prevladale tačke oslonca na zapamćenu zajedničku prošlost nad tačkama razdora predstavljala je dodela najvišeg priznanja Opštine Kraljevo - Diplome počasnog građanina - Borisu Soviču, županu Maribora, 2004. godine. ${ }^{5}$ U uzvratnoj poseti, 14. oktobra 2007. godine, delegacija na čelu sa županom grada Maribora Francom Kanglerom prisustvovala je komemorativnoj sednici, a potom položila venac na Spomen-groblju. ${ }^{6} \mathrm{Kao}$ izraz posebnog poštovanja „za dugogodišnje angažovanje na uspostavljanju partnerskih odnosa između Kraljeva i Maribora i velike pomoći Maribora Kraljevu u periodu obnove nakon zemljotresa“, Francu Kangleru je na svečanoj sednici održanoj na Dan Kraljeva, 7. oktobra 2012. godine, dodeljeno zvanje počasnog građanina grada Kraljeva. ${ }^{7}$ Naime, kada je Kraljevo 3. novembra 2010. godine pogodio zemljotres, odlukom gradskih većnika, grad Maribor je već 29 . novembra, među prvima, uputio sredstva za obnovu gradske bolnice i za pomoć ugroženim građanima u Kraljevu. ${ }^{8}$ Gest humanosti i solidarnosti je grad Maribor ponovio 2014. godine - slanjem spasilačkih ekipa u Obrenovac,

\footnotetext{
${ }^{5}$ Služba protokola grada Kraljeva, dokumentacija o dodeli nagrada i priznanja Opštine Kraljevo i grada Kraljevo, neinventarisano.

${ }^{6}$ Ibarske novosti, Kraljevo, 19. 10. 2007, 2.

${ }^{7}$ Štajerske novice, Maribor, 8. 10. 2012.

8 Plakat: Humanitarna pomoć od 40.000 eura koju Mestna občina Maribor, Odlukom gradskog veća od 29. 11. 2010, dodeljuje Opštini Kraljevo pogođenoj zemljotresom, dokumentacija Udruženja „Prijateljstvo za nova vremena" u Kraljevu.
} 


\section{S. Krejaković \\ Eho ratne traume: na dugim prugama...}

kao i slanjem materijalne pomoći ugroženima u poplavama u Srbiji, među kojima je bilo i meštana kraljevačkog područja. ${ }^{9}$

\section{Polazište: istorijska mapa}

Zapitanost nad uzrocima uspostavljenih korelacija neophodno upućuje na sagledavanje prošlosti. Kraljevo je privredno uznapredovalo posle Prvog svetskog rata, a neprestani demografski rast 30-tih godina prošlog veka načinio ga je etnički i verski heterogenom sredinom, u kojoj su se prožimali narodi, jezici, kulture, i to ponikli iz svih oblasti zajedničke države i van nje. Među žiteljima Kraljeva je 1931. godine zabeleženo i 655 rimokatolika, ili gotovo $10 \%$ gradskog stanovništva, pretežno Slovenaca, i u manjem broju Čeha, Slovaka i Hrvata (Virijević 2006, 42-43). Prvim migracijama Slovenaca u Kraljevo u međuratnom periodu doprineli su uslovi rada i zarada $u$ fabrikama aviona i vagona, potom stručne razmene i saradnja sa srodnim fabrikama u Sloveniji, ali i državna politika integralnog jugoslovenstva. Kao izraz bliskosti sa sredinom $u$ koju su došli, kraljevačka župna Crkva Sv. Mihaela osveštana je 18. novembra 1933. godine, da u bogosluženju okupi rimokatoličke vernike (župa je obuhvatala teritoriju od Stalaća i Užica do Raške i Gornjeg Milanovca). Tom prilikom su osveštana i zvona - poklon kralja Aleksandra Karađorđevića. Pomenuta crkva bila je mesto utehe u ratnim godinama koje su usledile (Jovanović 2015, 44-51). Kraljevo, među najvažnijim železničkim čvorovima, mesto gde su se ukrštale pruge ka Skoplju i Beogradu, sa fabrikama za remont pri železnici i u avio-industriji, predstavljalo je stecište stručnih radnika i službenika različitog porekla i delatnosti. Postalo je, neumitno, veliko izbegličko utočište - najpre slovenačkog stanovništva, potom i izgnanika iz NDH, te preseljenika sa Kosova i Metohije.

Usled okupacionih podela teritorija nekadašnje Dravske banovine, kao ekspanzionih ciljeva nemačkog nacizma i italijanskog fašizma i prisilne germanizacije, prugama ka Srbiji krenuli su transporti slovenačkih izgnanika. Železničke kompozicije su prema smernicama za preseljavanje Slovenaca trasirale put u neizvesnost. Ujedno su stavljale slovenačko stanovništvo pred grube i detaljne preglede i rasno ocenjivanje. U strogo kontrolisanom izbegličkom prtljagu

\footnotetext{
${ }^{9}$ Dokumentacija Udruženja „Prijateljstvo za nova vremena" u Kraljevu, plakat: Humanitarna pomoć od 40.000 eura dodeljena Kraljevu Odlukom gradskog veća Maribora od 8. 6. 2014, u potpisu: župan dr. Andrej Fištavec.
} 
moglo se naći 30 kilograma ličnih stvari, odeća i pokrivač, hrana za 8 dana, lična dokumenta i 400 dinara gotovine (Milošević 1981, 34-35). Kada je u prvom izbegličkom transportu iz Štajerske, iz sabirnog logora u Mariboru, 7. juna 1941. godine deportovano u Srbiju 4.669 osoba, za mnoge je izbeglice, posle privremenog prihvata $\mathrm{u}$ Jagodini, Ćupriji, Paraćinu, Vrnjačkoj Banji, Aranđelovcu, Trsteni$\mathrm{ku}$, Kragujevcu, daljim rasporedima, poslednja stanica bila u Kraljevu. Za njima su, svake nedelje, na mučno i dugo putovanje kretala po dva transporta sa oko 300 izgnanika u svakom (Marinković i dr. 1978, 20).

Prihvat prvih slovenačkih izgnanika $u$ Kraljevu organizovao je Odbor za zbrinjavanje izbeglica, formiran tokom juna 1941. godine, samoinicijativom materijalno imućnijih, a humanizmom podstaknutih građana. Oni su se brojnim apelima i ličnim primerom angažovali na prikupljanju priloga u novcu, hrani, odeći i ogrevu. ${ }^{10}$ Pomoć ugroženima ovim putem bila je izuzetno važna u vreme kada institucije na državnom nivou (Komesarijat za izbeglice i preseljenike) još nisu stvorile ni jedinstveni plan rasporeda naseljavanja izbeglog stanovništva (Milošević 1981, 258). Podsticaj koji su mogli imati građani razorenih srpskih gradova i seosko stanovništvo da prihvate prve transporte slovenačkih izbeglica nije precizno objašnjiv, osim što se može tražiti u poštovanju različitosti od ranije prisutne slovenačke kolonije i u saosećanju zbog egzistencijalne ugroženosti od strane zajedničkog neprijatelja. Druga etapa iseljavanja Slovenaca sprovedena je do kraja jula 1941. godine. Tada je sabirni logor u Meljskoj kasarni u Mariboru trebalo predati nemačkim vojnim vlastima. Zbog toga je dolazilo do užurbanih hapšenja civila u širem području Maribora, u okruzima Celje, Trbovlje i Ptuj, kao i u Rogaškoj Slatini, odnosno - sve od Maribora do slovenačkog dela Zagorja. Iz Maribora je u preriodu od 11. do 26. jula krenulo 14 transporta sa oko 6.000 izgnanika u logor u Slavonskoj Požegi. Tu se nalazilo raskršće pruga koje su vodile ka Slavoniji i zapadnom Sremu, kao delu NDH, i preko Bosne. U Slavonskoj Požegi je iz izbegličkih transporta zaustavljeno 3.300 Slovenaca. Oni su upućeni dalje ka Srbiji (Hamović 1994, 393). Vojni izveštaji okupacionih snaga iz

\footnotetext{
${ }^{10}$ Narodni muzej Kraljevo (dalje NMK), zbirka: arhivalije, dokument: Apel za pomoć izbeglicama, Odbora za zbrinjavanje izbeglica u Kraljevu, sa potpisima članova, inv. br. 1096. U sadržaju dokumenta „umoljava se“ prilog od 1.000 dinara, koji je potrebno do 10. 6. 1941. dostaviti Odboru preko Crvenog krsta, u porti Pravoslavne Crkve „Sv. Trojice“ u Kraljevu.
} 


\section{S. Krejaković}

Eho ratne traume: na dugim prugama...

Slovenije navode: „Slovenci se upućuju u Srbiju gde ih stanovnici bratski dočekuju. Slovenačka kolonija u Srbiji, koja je pre rata imala oko 200.000 ljudi, od kojih 40.000 u Beogradu, vrlo je bogata i imućna i prikupila je, pojedinačno upisujući, velike iznose za pomoć tim prognanicima. Izgleda takođe da u Srbiji ima obilje hrane i da zbog toga taj priliv ljudstva nije izazvao poremećaj u ekonomiji." ${ }^{11}$
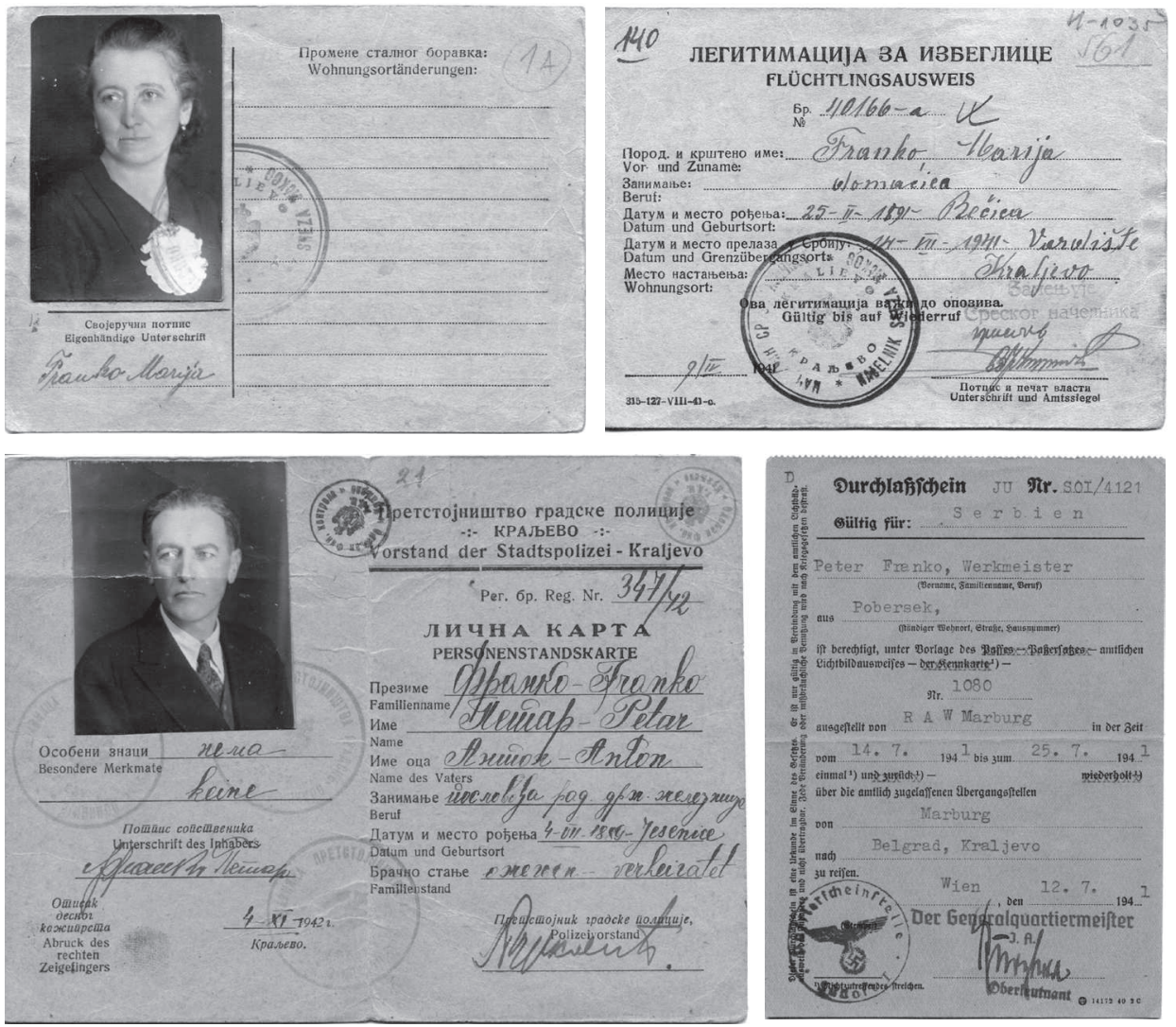

Dokumenti Marije i Petera Franka, izbeglica iz Maribora: vozna karta na relaciji Marburg-Beograd, Kraljevo, izdata 12. 7. 1941. (NMK, inv. br. 1033), i legitimacija za izbeglice (NMK, inv. br. 1035)

Okupaciona štampa navodi da je do jula 1941. godine u Kraljevo pristiglo 1.500 izbeglica. ${ }^{12}$ Broj izgnanika se šest meseci kasnije po-

${ }^{11}$ Zbornik NOR-a VII JNA, VI-1, dok. br. 101: „Bilten obaveštajnog odeljenja komande italijanskog 11. armijskog korpusa od 12. jula 1941. godine“, 267-268

${ }^{12}$ Novo vreme, god. I, 5. jul 1941. 
peo na $2.230 .{ }^{13}$ Popisi izbeglica, koje su po teritorijalnom rasporedu uradili odbori (sreski i okružni) Komesarijata za izbeglice i preseljenike pri srpskoj vladi, pouzdano i precizno utvrđuju broj izbeglica, zatim pregled mesta i oblasti iz kojih su izgnani, kao i onih mesta u koje su izbegli pristizali. Ove evidencije statistički su pokazatelj etničke, socijalne, starosne i verske strukture, a posredno govore o napuštenim domovima, izgubljenom imetku, napuštenim zanimanjima, navikama, izgrađenim međuljudskim odnosima. ${ }^{14} \mathrm{Na}$ teritoriji Kraljeva (Ribnica, Grdica, Adrani), do 9. septembra 1942. godine bile su evidentirane 993 izbegličke porodice, sa ukupno 2.837 članova („preseljenici“ sa Kosova - 272 domaćinstva; iz Makedonije 227; iz NDH - 245; iz Sandžaka - 46), među kojima i 41 porodica iz Slovenije (Krejaković 2009, 69-85). Rudi Štajnbüher je svoja dragocena sećanja na egzodus u Kraljevu obogatio prikazom položaja proteranih Slovenaca, svojih prijatelja i kolega (Steinbücher 1988). ${ }^{15}$ On se, sa stečenim predratnim iskustvom železničkog činovnika u Mariboru, zaposlio u kraljevačkoj Železničkoj radionici. Ovo je iskustvena priča o životu u okupiranom Kraljevu, gde su uslovi za život, smeštaj, prehranu i zapošljavanje bili sve teži sa svakim danom okupacije, naročito kada usled ustaničkih napada na nemački garnizon dolazi do blokade grada, racije i streljanja njegovog stanovništva u oktobarskoj masovnoj odmazdi. Dodatna vrednost njegovih memo-

\footnotetext{
${ }^{13}$ Novo vreme, god. II, 12. februar 1942.

${ }^{14} \mathrm{U}$ stalnoj postavci NMK-a izloženi su dokumenti izbegličke porodice Franko iz Maribora: nemačka propusnica za put u Srbiju, izdata 11. 7. 1941. (inv. br. 1033); lekarska potvrda za dozvolu putovanja, izdata nakon pregleda 21. 6. 1941. (inv. br. 1031); izbegličke legitimacije Marije i Petera Franka, datovane 9. 4. 1942. (inv. br. 1035); platna knjižica Železničke radionice, Petera Franka, od 1. 5. 1942. do 1. 9. 1944. (inv. br. 1032).

15 U knjizi su, među streljanim Slovencima, navedene i osobe za koje etnička pripadnost nije pouzdano utvrđena: Hauberg Josip, rođen 14. 5. 1909. Beograd, elektičar, Žel. ložionica; Bobić Zvonimir, 1914. Split, mehaničar Fabrike aviona; Žuža Danilo, Ljubinje, limar Fabrike aviona; Kirn Albert, od oca Franja, 24. 5. 1898. Donji Vakuf; Katič Franjo, 21. 11. 1900, Kolonić, Bosanski Petrovac; Laci Horvat, 30. 6. 1899. Velika Kanjiža (tada mađarska okupaciona zona). Podaci navedeni prema: NMK, spiskovi (april/maj 1942): Železničke ložionice (inv. br. 91); Železničke radionice (inv. br. 99 i 119; Fabrike aviona (inv. br. 109-111); Načelstva Žičkog sreza (inv. br. 89).
} 
ara je u tome što približava likove, sudbine, živote streljanih kolega Slovenaca, o kojima su sačuvani samo šturi podaci u istorijskim izvorima (Krejaković 2013).

Ratni zločin protiv čovečnosti, koji su počinile jedinice nemačkog Vermahta, sprovodio se usled isključive ideologije nacizma o vrednosti sto života civila u Srbiji naspram jednog ubijenog nemačkog vojnika i pedeset života civila za jednog ranjenog vojnika. U istorijskim izvorima, pre svega u spiskovima streljanih u oktobru 1941. godine, sastavljenim prema naredbi Okružnog načelstva, zabeležena su imena i podaci o „voljnim i nevoljnim“ migrantima onima koje su povoljni socijalni uslovi u međuratnom periodu, ili nepovoljne okolnosti ratnog izgnanstva, doveli u Kraljevo. ${ }^{16}$ Sudbine Slovenaca objedinjene su u zlohudom vremenu sa sudbinama ostalih talaca, zatvorenih u lokomotivskoj hali i streljanih u krugu Železničke radionice. U slučaju personalizacije podstaknute analizom istorijskih izvora, suočeni smo, međutim, i sa zamkama koje se tiču etničke pripadnosti - pritajeno usidrenim u specifičnim banovinskim teritorijalnim podelama predratne Jugoslavije i okupacionim promenama granica (Krejaković i dr. 2011). Među najmanje 2.194 civilne žrtve, čija su imena utvrđena istraživanjem izvora, pale u ratnom zločinu u oktobru 1941. godine, koji je brutalno promenio istoriju grada, strukturu njegovog stanovništva, ali pre svega razorio lične i porodične živote, streljano je 50 Slovenaca (Krejaković 2013). Podaci u izvorima, prema kojima je $21 \%$ ukupnih lagerskih žrtava obavljalo stručne poslove u Fabrici aviona, 31\% u Železničkoj radionici (Fabrika vagona), Železničkoj ložionici i u službama na železnici, odgovaraju i socijalnoj strukturi slovenačkih žrtava (Krejaković 2013). Samo nekolicina Slovenaca spasila se od streljanja koristeći slabosti birokratskog sistema nemačke Komande mesta i svoje znanje nemačkog jezika, a bar dvojici, Zmagu Hrenu i Matku Rotaru, uspelo je da pobegnu sa stratišta. Njihova sećanja su dragocena direktna svedočanstva o streljanju (Kraljevo oktobra 1941 - kaziva-

\footnotetext{
16 NMK, zbirka arhivalija: Spisak stradalih lica Žičkog sreza u vreme komunističkih nereda, Okružno načelstvo u Kraljevu, 28. maja 1942. (inv. br. 89). U provenijenciji ovog nadleštva (nadležnost nad više srezova, među kojima u Žičkom - Kraljevo sa širom okolinom), navedenim spiskom su objedinjeni svi prethodno dostavljeni spiskovi iz fabrika, škola, ustanova, koji beleže osnovne poimenične podatke o svojim ljudskim gubicima, sa podacima o nezaposlenim civilima koji su „streljani u lageru“, ili su stradali na druge načine.
} 
nja preživelih 1966, 31-35; 88-92). Kako je najveći broj streljanih u oktobru 1941. godine bio starosti između 25 i 45 godina života, celovitu sliku civilnog stradanja u oktobru 1941. u Kraljevu upotpunjuju i posredni fragmenti zločina počinjenog protiv čovečnosti: porodice koje su izgubile hranitelje, ratna siročad, opustošena privreda...

Edo Gnuišek se je sa prstima obe ruke naslonio na staklo prozora i čuo sam kad je rekao: „Sine moj!“ Ja sam stojao na hodniku i čekao. I čuo sam kao što sam čuo već toliko puta dnevno. Čuo sam grmljenje mitraljeza i zatim pojedinačne pucnjeve. Tad sam mislio da će mi pući srce. Mnogo lakše, mnogo lakše bilo bi mi, ako bi ti meci prošli kroz moje telo. Dane, mesece, godine i godine nisam se mogao otarasiti te slike (Steinbücher 1988, 88).

Krah humanosti od 1941. godine, kada je - osim lagerskog - u skoro svim selima na kraljevačkom području postojao niz manjih stratišta, ispoljavao se i u godinama okupacije koje su usledile, pogađajući civile, a među njima i socijalno najugroženiji sloj - izbeglice. Slovenci su nemaštinu, strah od učestalih odmazdi okupacione svakodnevice, strepnju od racija i sprovođenja policijskog časa, volju da se uključe u akcije pokreta otpora, kao izbeglice sa „najdužim stažom “ među izgnanicima, podelili sa lokalnim stanovništvom.

Po izveštajima Komesarijata, od 1. marta 1942. godine, na teritoriji Kraljevačkog okruga, koji je obuhvatao široko područje (Kraljevo, Guča, Preljina, Ivanjica, Čačak), nalazilo se ukupno 3.013 izbeglica, među kojima 879 Slovenaca; u samom Kraljevu je do navedenog datuma zabeleženo ukupno 2.155 izgnanika, među kojima 168 Slovenaca (Hamović 1994, 484). Bekstvo ljudi iz grada intenzivirano je posle bombardovanja angloameričkih saveznika u leto 1944 . godine, kada je u pogođenim objektima, mimo strateški utvrđenih ciljeva, poginuo i veliki broj civila. U najrazornijem bombardovanju Kraljeva, u noći 10/11. avgusta 1944. godine, oštećeno je krilo katoličke Crkve „Sv. Mihovila“i porušen zvonik, a među žrtvama su bili i župnik Rudolf Mercilovšek i profesorka klavira Marijeta Karba (Steinbücher 1988, 203).

Prodor jedinica NOVJ u Srbiju, u čije su se borbene redove uključili i mnogi slovenački izgnanici, i velike borbe koje su usledile nisu dozvoljavali povratak izbeglicama u ranija prebivališta. Kada je oružje utihnulo, a izbeglištvo - eliminisanjem uzroka koji su do njega doveli - prestalo da postoji, mogućnost uposlenja zadržala je samo deo nekadašnjih slovenačkih izgnanika u Kraljevu. 


\section{S. Krejaković}

Eho ratne traume: na dugim prugama...

\section{Umesto zaključka}

Spone koje su povratnike u Sloveniju, u godinama koje su usledile posle Drugog svetskog rata, vezivale sa mestom nekadašnjeg utočišta proizašle su iz vremena zajedničkih ratnih nevolja. Vozovi na relaciji nekadašnjih trasa izbegličkih transporta, nazivani vozovima bratstva-jedinstva, kao manifestacija zbratimljenih gradova u Srbiji i Sloveniji, uspostavljeni su na nekadašnjem sapatništvu, ljudskom senzibilitetu i sećanju, mnogo čvršće nego što su to predstavljali zahtevi aktuelne ideologizacije. Još uvek živi lični odnosi, kulturna i privredna saradnja između srpskih i slovenačkih gradova, ali i humani gest pomoći pri sanaciji posledica zemljotresa 2010. godine i pomoć ugroženima u poplavama u Srbiji 2014. godine, koju su Republika Slovenija i, posebno, grad Maribor uputili Kraljevu, nedvosmisleno ovo potvrđuju.

Tabela: Slovenci streljani u Lageru u Kraljevu 15-20. oktobra 1941. Izvor: NMK, baza podataka o žrtvama II svetskog rata

\begin{tabular}{|l|c|l|l|l|}
\hline \multicolumn{1}{|c|}{ Prezime i ime } & $\begin{array}{c}\text { God. } \\
\text { rođ. }\end{array}$ & \multicolumn{1}{|c|}{ Mesto rođenja } & Zanimanje & Mesto zaposlenja \\
\hline Arnšek Jože & 1903. & Blanca & krojač & Fabrika aviona \\
\hline Aleksič Anton & 1908. & $\begin{array}{l}\text { Središče, Murska } \\
\text { Sobota }\end{array}$ & bravar & Žel. radionica \\
\hline Batagelj Janez & 1925. & Maribor & učenik & \\
\hline Batagelj Pavel & 1890. & Kranj/Sežana (?) & stolar & Žel. radionica \\
\hline Cimerman Josip & 1879. & Tržič & bravar & \\
\hline Čižek Karlo & 1909. & Sveti Jurij & stolar & Žel. radionica \\
\hline Čuk Ernest & 1920. & Ššstanj & električar & Fabrika aviona \\
\hline Čuk Ludvig & 1909. & Rača, Maribor & radnik & Fabrika aviona \\
\hline Čebohin Albin & 1905. & Divača & stolar & Žel. radionica \\
\hline Fatur Stanislav & 1904. & Trst & poslovođa & Žel. radionica \\
\hline Gabrijelčič Ignac & 1895. & Slovenska Gorica & zidar & Žel. radionica \\
\hline Gniušek Borut & 1921. & Maribor & tehničar & Fabrika aviona \\
\hline Godar Štefan & 1897. & Murska Sobota & zidar & \\
\hline Grdina Anton & 1892. & Movraž & zidar & Fabrika aviona \\
\hline Godec Jožef & 1913. & Poljčane & & \\
\hline Hibl Emil & 1892. & Trst & poslovođa & Žel. radionica \\
\hline Jenić/Janić Svetozar & 1915. & Trst & bravar & Fabrika aviona \\
\hline Jermol Alojz & 1892. & Idrija & bravar & Fabrika aviona \\
\hline Kartnik Ferdinand & 1916. & Jesenice & bravar & Fabrika aviona \\
\hline Kovačič Drago & 1910. & Trst & činovnik & Žel. radionica \\
\hline Kramberger Miroslav & 1910. & Maribor & činovnik & Žel. radionica \\
\hline Krlej Franc & 1915. & Maribor & bravar & \\
\hline Kunti Franc & 1916. & Sežana & bravar & Žel. radionica \\
\hline
\end{tabular}




\begin{tabular}{|l|c|l|l|l|}
\hline \multicolumn{1}{|c|}{ Prezime i ime } & $\begin{array}{c}\text { God. } \\
\text { rođ. }\end{array}$ & \multicolumn{1}{|c|}{ Mesto rođenja } & \multicolumn{1}{|c|}{ Zanimanje } & \multicolumn{1}{|c|}{ Mesto zaposlenja } \\
\hline Lah Vasilij & 1920. & Maribor & inženjer & Fabrika aviona \\
\hline Lovrenčič Alojz & 1896. & Ilirska Bistrica & činovnik & Žel. ložionica \\
\hline Lorbek Alojz & 1898. & Lenart & slovopisac & Žel. radionica \\
\hline Margon Anton & 1898. & Trnje & ložač & Žel. ložionica \\
\hline Možina Valentin & 1908. & Slavina & zidar & Žel. radionica \\
\hline Novak Alojz & 1904. & Ptuj & zidar & Fabrika aviona \\
\hline Novak Josip & 1903. & Ljubljana & bravar & Žel. radionica \\
\hline Peneš Alojz & 1906. & Celje & bravar & Fabrika aviona \\
\hline Perhavec Florijan & 1909. & Vipava & farbar & Žel. radionica \\
\hline Perič Slavko & 1910. & Opatje, Gorica & bravar & Fabrika aviona \\
\hline Perper Vinko & 1911. & Krško & vojni narednik & \\
\hline Petrovič Franc & 1920. & Dravograd & trg. pomoćnik & \\
\hline Primožič Josip & 1913. & Trst & radnik & Fabrika aviona \\
\hline Ramšak Simon & 1909. & Poljčane & probni pilot & Aerodrom Kraljevo \\
\hline Rustja Josip & 1902. & Ajdovščina & stolar & Žel. radionica \\
\hline Stefančič Arnšak & 1924. & Slovenska Gorica & radnik & Aerodrom \\
\hline Stibil Franjo & 1906. & Slovenska Gorica & stolar & \\
\hline Štalekar Karel & 1920. & Brno & strugar & Žel. radionica \\
\hline Štekar Radko & 1923. & Slap, Ajdov̌̌čina & limar & Fabrika aviona \\
\hline Tretjak Ivan & 1923. & Maribor & radnik & Fabrika aviona \\
\hline Turk Franc & 1920. & Škofja Loka & tehničar & Fabrika aviona \\
\hline Vidmar Eduard & 1906. & Godovići & & \\
\hline Vilfan Franc & 1896. & Ljubljana & stolar & Žel. radionica \\
\hline Virant Miroslav & 1910. & Bohinjska Bela & činovnik & Služba pošte i telegrafa \\
\hline Zorko Alojzij (Slavko) & 1920. & Slovenska Gorica & radnik & Žel. radionica \\
\hline Zupančič Feliks (Srećko) & 1907. & Žužemberk & bravar & Žel. ložionica \\
\hline Žvab Vinko & 1915. & Vrhovlje & strugar & Fabrika aviona \\
\hline & & & & \\
\hline
\end{tabular}

Izvori:

Grad Kraljevo, Odeljenje matične službe: Protokoli umrlih Srpske pravoslavne crkve (1933 - 1948); Matice pokojnih, Rimokatoličkog župskog ureda crkve Sv. Mihovila u Kraljevu (1934 - 1946).

Istorijski arhiv Kraljevo, fond: Opština kraljevska 1918 - 1941; Skupština sreza Kraljevo (1944 - 1967)

Narodni muzej Kraljevo, zbirke: arhivalije i predmeti streljanih u lageru; plakati, leci; realije i memorijalni predmeti (1941 - 1944).

Zbornik dokumenata i podataka o narodnooslobodilačkom ratu jugoslovenskih naroda, Vojnoistorijski institut JNA Beograd, tom 1, knj.2, 1949; tom VI, knj.1, 1952. 
Literatura

Borba. 1961. Dirljivi susreti starih prijatelja. Borba (Beograd) 243, 19. septembar : 5.

Dimić, Ljubodrag. 1994. Istoriografija i ideologija - jugoslovensko iskustvo 1945-1955. Godišnjak za društvenu istoriju1(1) : 35 - 54.

Glišić, Venceslav. 1970. Teror i zločini nacističke Nemačke u Srbiji 1941 - 1944. Beograd : Institut za istoriju radničkog pokreta Srbije.

Hamović, Miloš.1994. Izbjeglištvo u Bosni i Hercegovini (1941 - 1945). Beograd : Biblioteka posebnih izdanja.

Janićijević, Dušan. 1999. Dobrovoljni rad omladine Kraljeva 1945 - 1999. Kraljevo : Društvo akcijaša „Ibar“.

Jončić, Koča. 1971. Kraljevački oktobar 1941. Beograd : Ekonomska politika i KPZ.

Jovanović, Zoran M. 2015. Istorija kraljevačke župe Sv. Mihaela Arkanđela verna slika naše istorije. Beograd : Beogradska nadbiskupija.

Kraljevo oktobra 1941 - kazivanja preživelih.1966. Kraljevo : Opštinski odbor SSRNS.

Kraljevo oktobra 1941. 2003. Zbornik radova sa okruglog stola (15 - 16.10 2001). Kraljevo : NMK.

Krejaković, Silvija. 2009. Slovenci izbeglice u Kraljevu u vreme okupacije (1941 - 1944). Naša prošlost 10 : 139 - 155.

Krejaković, Silvija i Urška Strle.2011. Rekvijem za harmoniku: Slovenci $\mathrm{u}$ kontekstu masovne odmazde $\mathrm{u}$ Kraljevu. Dvedomovini / TwoHomelands $33: 73-88$.

Krejaković, Silvija. 2013. Identiteti žrtava streljanih u Kraljevu oktobra 1941. Beograd : Muzej žrtava genocida.

Krejaković, Silvija i Suzana Novčić. 2015. Kultura sećanja - Ko ne pamti iznova proživljava : katalog izložbe. Kraljevo : Narodni muzej.

Manoschek, Walter. 1993. „Serbien ist judenfrei“ - Militarische Besatzungspolitik und Judenvernichtung in Serbien 1941/42. Munchen : R. Oldenbourg Verlag.

Marinković, Radovan M. i Miroslav Mile Mojsilović.1978. Svedočanstva / Pričevanja. Čačak : Čačanski glas.

Milošević, Slobodan D.1981.Izbeglice i preseljenici na teritoriji okupirane Jugoslavije (1941-1945). Beograd : Institut za savremenu istoriju.

Pavlović, Mirjana. 2016. Od bratstva i jedinstva do prijateljstva za nova vremena : Maribor - Kraljevo. Glasnik Etnografskog instituta SANU $64(1): 51-65$.

Petranović, Branko. 1992. Srbija u II svetskom ratu (1939-1945). Beograd : Vojnoizdavački i novinski centar.

Radović, Radmila i Jasminka Marković. 2016. „Voz bratstvo-jedinstvo“ Maribor - Kraljevo (1961 - 1989) : katalog izložbe. Kraljevo : Istorijski arhiv. 
Simić, Mihailo. 1983. Kraljevo oktobra 1941: svedočenja i sećanja. Beograd : Srpska književna zadruga.

Steinbücher, Rudi.1988. Oj, zdaj gremo. Slovenski izgnanci v Kraljevu. Ljubljana : Založba Borec.

Stanojević, Vladica. 1991. Prijateljstvo u plamenu. Ibarske novosti (Kraljevo) $4.7: 1$.

Virijević, Vladan. 2006. Kraljevo, grad u Srbiji (1918-1941). Kraljevo : NMK : IAK.

Silvija Krejaković

Narodni muzej Kraljevo

Srbija

silvija.krejakovic@gmail.com

\section{ODMEV VOJNE TRAVME: NA DOLGIH PROGAH MED MARIBOROM IN KRALJEVIM}

V članku so analizirane korelacije med Mariborom in Kraljevim, ki so se v preteklosti vzpostavile na medčloveških odnosih. Tekst spremlja genezo teh odnosov, od migracij Slovencev, ki so svoje prebivališče v medvojnem obdobju ali begunsko zatočišče med drugo svetovno vojno našli na področju Kraljeva, do odmeva travmatične preteklosti prek povojnih manifestacij: »Povelja« o bratenju Maribora in Kraljeva, vlakov »Bratstva in edinstva « in memorialov v Spominskem parku v Kraljevu. Poudarek je na vzorcih kolektivnih prisilnih migracij, z osredotočanjem na v času okupacije socialno in družbeno najbolj ogrožen demografski sloj. To so bile žrtve vojnih aspiracij in odločitev sil moči, na katere niso mogle vplivati, vendar so zaradi njih izgubile bližnje, dom, imetje, status. Slovenski begunci so s prebivalci Kraljeva in njegove okolice, med katerimi so bili tudi njihovi sonarodnjaki, s predvojnimi strokovnjaki in uradniki mestnih tovarn ter železniškega vozlišča delile okupacijske muke - življenje $\mathrm{v}$ pomanjkanju in strah pred nasilno smrtjo na hišnem pragu ali v množičnih maščevanjih, med katerimi so se najbolj pogubna vršila v taborišču Kraljevo, v oktobru leta 1941. Poudarjeni zasebni, družinski fragmenti so v kolektivni podobi skupne travmatične preteklosti obravnavani tudi prek refleksij kasnejših odnosov med ljudmi z dveh oddaljenih geografskih področij.

Ključne besede: migracije, vlaki, druga svetovna vojna, Slovenija, begunci, Kraljevo, streljanje, taborišče 


\author{
Silvija Krejaković \\ National Museum, Kraljevo \\ Serbia \\ silvija.krejakovic@gmail.com
}

\title{
THE ECHOES OF WAR TRAUMA: ALONG THE LONG TRAIN TRACKS BETWEEN MARIBOR AND KRALJEVO
}

The paper analyzes the links between Maribor and Kraljevo that are based on interpersonal relations in the past. The study tracks the genesis of these relations, from the migrations of Slovenians who found their home (in the interwar period) or a refugee shelter (in World War II) in the Kraljevo region, to the echoes of the traumatic past in post-war cultural events: the Maribor-Kraljevo Twinning Charter, the Brotherhood-and-Unity trains, the memorials at the Memorial Park in Kraljevo. It highlights the causes of collective forced migrations and focuses on what was the socially most vulnerable demographic stratum during the Nazi occupation. These were the victims of the wartime aspirations and decisions of the forces of power, beyond the victims' influence, due to which they lost their loved ones, their homes, their property, their status. Slovenian refugees shared the hardship that accompanied the occupation the life in poverty and the fear of being killed at their doorstep or during the acts of mass retaliation, the deadliest of which was the one at the local rolling-stock factory, in October 1941 - with the inhabitants of Kraljevo and the surrounding areas, including their compatriots, pre-war trained workers and clerks at the factories in Kraljevo and the railroad hub. The highlighted personal, family fragments in the collective image of a shared traumatic past are also analyzed through their reflections in later relationships between people in two distant regions.

Keywords: migrations, trains, World War II, Slovenia, refugees, Kraljevo, shooting, rolling-stock factory 